\title{
Meropenem Anhydrous
}

National Cancer Institute

\section{Source}

National Cancer Institute. Meropenem Anhydrous. NCI Thesaurus. Code C61833.

The anhydrous form of meropenem, a broad-spectrum carbapenem with antibacterial properties, synthetic Meropenem inhibits cell wall synthesis in gram-positive and gramnegative bacteria. It penetrates cell walls and binds to penicillin-binding protein targets. Meropenem acts against aerobes and anaerobes including Klebsiella, E. coli, Enterococcus, Clostridium sp.. ( $\mathrm{NCl04)}$ 